\title{
Historical review. The light and shadow of Paul Kaznelson: his life and contribution to hematology
}

\author{
Yataro Yoshida
}

Received: 17 June 2008 / Accepted: 26 June 2008 / Published online: 22 July 2008

(C) The Author(s) 2008. This article is published with open access at Springerlink.com

\begin{abstract}
Paul Kaznelson is credited with describing the first case of pure red cell aplasia. He was also known for his contribution to the discovery of the therapeutic role of splenectomy in idiopathic thrombocytopenic purpura. Most of his academic works appeared in 1910s and 1920s, when he used to work in Karl-Ferdinand University in Prague. Trail of his rather tragic postwar life is briefly added.
\end{abstract}

Keywords PRCA $\cdot$ Platelet $\cdot$ ITP $\cdot$ Review

\section{Pure red cell aplasia}

Most reviews on pure red cell aplasia (PRCA) list Kaznelson as the author of the first case [1] but rarely mention how he came to recognize the hitherto unknown unilineage cytopenia. Unilineage cytopenia is defined as peripheral cytopenia of a given blood cell lineage together with the absence or a severe reduction in progenitor cells of the same lineage. Its detection requires insight into the progenitor-progeny relationship of blood cells. In this regard, it is not surprising that the original article by Kaznelson was entitled as the origin of platelets. His primary interest in hematology was platelets. Bizzozero discovered platelets in 1881 and even earlier noted the presence of giant multinuclear cells in the bone marrow, conceivably megakaryocytes [2]. The suggestion of megakaryocytes as the platelet progenitor was made by

Y. Yoshida $(\bowtie)$

Center for Hematological Diseases, Takeda General Hospital,

28-1 Ishida-Moriminami, Fushimi-ku,

Kyoto 601-1495, Japan

e-mail: yoshida@takedahp.or.jp
Wright in 1906 [3], who noted the similarities in shape and color of granules in platelets and megakaryocytes using his Wright's staining. However, the origin of platelets was still the subject of debate in 1920s. For instance, Schilling held the view that the nuclei of the erythroblasts play a role in platelet formation [4]

The patient was a 58 -year-old man with a rapidly progressive anemia. The red cell count was $0.55 \times 10^{12} / 1$ with normal leukocyte count, differential count, and platelet count. The marrow at autopsy showed complete absence of the erythroid series sparing the granulopoietic and megakaryocytic elements. This case is in line with the Wright's theory that the origin of platelets is megakaryocytes but not erythroid cells. If the latter cells, the patient's platelet count would have been equally low. Kaznelson concluded that this finding is not compatible with the Schilling hypothesis that marrow erythroblasts are the platelet progenitor. Thus, the title as well as the case speaks itself. Of note is the fact that Kaznelson described the first case of an acquired PRCA well ahead of the seminal paper on congenital PRCA by Blackfan and Diamond [5]. The recognition of amegakaryocytic thrombocytopenia came much later on [6]. In hindsight, Kaznelson is qualified to have made the significant observation for two reasons. Being a platelet-oriented scientist, he had due knowledge on the staining of platelets and on the controversy concerning the origin of platelets. Moreover, he has had some experience in the bone marrow examination $[7,8]$.

\section{Splenectomy for the treatment of idiopathic thrombocytopenic purpura}

In addition, the name of Kaznelson is associated with the pioneering work of splenectomy in idiopathic thrombocyto- 
penic purpura (ITP). In 1916, though he was still a medical student, he hypothesized the analogy with hemolytic anemia that excessive destruction of the platelets occurs in the spleen [9]. He talked to his tutor, Professor Schloffer, to perform a splenectomy on a woman with chronic ITP. The professor followed his suggestion, and the first patient so treated showed a dramatic increase in her platelet count from $0.2 \times$ $10^{9}$ up to $500 \times 10^{9} / 1$ and disappearance of the purpura. Bleedings ceased in all three patients who underwent splenectomy. Since then, splenectomy has become the mainstay for the treatment in adult patients with refractory ITP, laparoscopic approach being common recently [10]. His paper on splenectomy is ranked the top fifth in a citation analysis of articles appearing in Wiener Klinische Wochenschrift between 1945 and 1988 [11]. Wiener Klinische Wochenschrift publishes articles written in German in all fields of medicine, and since hematology was only beginning to develop as a separate subspecialty with a relatively small number of hematologists, the analysis showing 79 citations is outstanding and tells us that splenectomy in ITP was the biggest single contribution Kaznelson made to hematology. The Nobel class work by Landsteiner on the discovery of ABO blood type appeared fourth with 86 citations, ahead of Kaznelson's by only one rank [11]. It took many decades after the first splenectomy until the pathogenesis of ITP and the role of spleen are recognized.

\section{Personal sketch of Paul Kaznelson}

Kaznelson was born in Warsaw, then a part of the Russian Empire, in 1892. After his father's death in Silesia, Germany, the family moved to Czechoslovakia, and he graduated from the German Karl-Ferdinand University in Prague in 1917. He acquired a Czechoslovakian nationality by naturalization in 1919. He joined the University faculty in 1926 and was appointed as Privatdozent in 1937. The days he worked there must have been his most productive and glorious time. His publications covered a wide range of topics from bleeding tendency, anemia to leukemia. An additional field of Kaznelson's interest lies in iron deficiency anemia and gastric acidity [12]. He was the first to note koilonychia in association with iron deficiency anemia [13].

His subsequent fate remained unknown until very recently, when the UK National Archives released a file into the public, which fortunately happened to provide pertinent information. The followings show how a brilliant scientist capable of publishing valuable articles while still young was forced to lead a rather distressing life. Because of his Jewish origin, he fled to Switzerland and further to France to escape the Nazis in 1939. He managed to land in Liverpool in 1940 at the age of 48. He remained in the UK throughout World War 2 working in many British hospitals. He returned to Prague after the war and resumed practice in the north of the Czech Republic. The communist Czech regime held his former education in a German University against him, not prepared to continue to validate his passport. He decided to return to the UK. He married to Katerina Pazderova, but they had no children. His wife had extensive land property and refused to leave Czechoslovakia.

Upon return to the UK, he applied for British nationality in 1950 , which turned out to be unsuccessful, though he was allowed to reside and work in the UK. We know of no reason for refusal of his application. Possession of certain properties in Berlin and Switzerland, former education in German University, occasional trips outside of UK, complex nationality being Russian by birth and parentage and Czech by naturalization with no formal certificate by the communists Czech regime, and his wife still in Prague might all in all have been unfavorable toward his application. One thing should not be overlooked, if any is that this was in the middle of the cold war with political tension and uneasiness prevailing world wide. Obviously, history did not favor him. He published only one brief communication, in which he showed his continued interest in splenectomy in ITP stating "having had the longest experience in this operation, I had watched its developmentlike a mother following the ways of her child" [14].

He died in 1959 in Germany. We are left with his photo showing a worn-out victim of the tragic fate, behind which one may envisage a bright and enthusiastic soul with keen insight in hematology (Fig. 1). In conclusion, Paul Kaznelson will be remembered for his numerous contributions as shown by 24 articles all but one written in German.

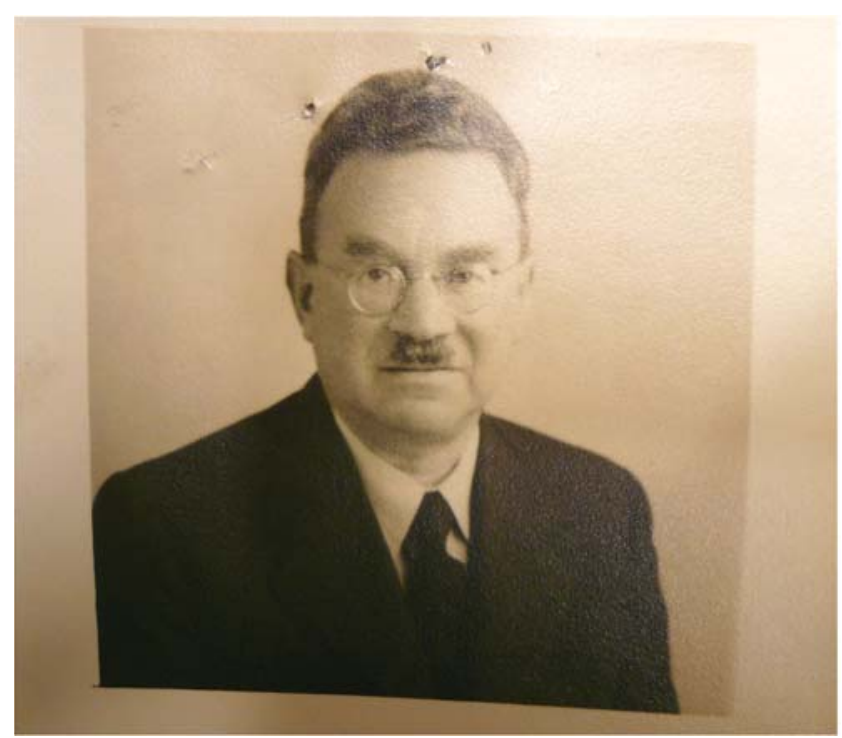

Fig. 1 Paul Kaznelson (appearing in his application for UK nationality 1950 , reproduced through courtesy of the UK National Archives) 
Acknowledgments The author is grateful to Drs. Neuvirtova R and Hlavackova L for the information on Kaznelson's activities in Prague. Special thanks are to The UK National Archives and Mr. Nixon RE for providing most valuable information.

Open Access This article is distributed under the terms of the Creative Commons Attribution Noncommercial License which permits any noncommercial use, distribution, and reproduction in any medium, provided the original author(s) and source are credited.

\section{References}

1. Kaznelson P (1922) Zur Entstehnung der Blutplättchen. Verhandlungen der Deutsche(n). Ges Innere Med 34:557-558

2. Ribatti D, Crivellato E (2007) Clinical review. Giulio Bizzozero and the discovery of platelets. Leuk Res 31:1339-1341 doi:10.1016/j. leukres.2007.02.008

3. Wright JH (1906) The origin and nature of the blood plates. Boston Med Surg J 154:643-645

4. Schilling V (1921) Die Zelltheorie des Erythrocyten als Grundlage der klinischen Wertung anämischer Blutbefunde. Virch Arch Path Anat 234:548-601

5. Diamond LK, Blackfan KD (1938) Hypoplastic anemia. Am J Dis Child 56:464-467
6. Boggs DR (1985) Amegakaryocytic thrombocytopenia. Am J Hematol 20:413-416 doi:10.1002/ajh.2830200414

7. Kaznelson P (1918) Seletene Zellformen des strömenden Bluten (Megakaryocyten, Histiocyten, Endothelien). Deutsch Arch Klin Med 128:131-150

8. Kaznelson P, Weiner W (1926) Über die zellige Zusammensetzung des Knochenmarkes nach Erfahrungen mittels der Sternalpunktion nach Seyfarth. Folia Haematol Leipzig 32: 233-261

9. Kaznelson P (1916) Verschwinden der hämorrhagische Diathese bei einem Falle von "essentieller Thrombopenie" (Frank) nach Milzextirpation. Splenogene thrombolytische Purpura. Wien Klin Wochenschr 29:1451-1454

10. Imbach P (2002) Historical review. Historical aspects and present knowledge of idiopathic thrombocytopenic purpura. Br J Haematol 119:894-900 doi:10.1046/j.1365-2141.2002.03755.x

11. Garfield E (1991) A citation analysis of Austrian medical research and Wiener Klinische Wochenschrift. Wien Klin Wochenschr 103:318-325

12. Kaznelson P, Reimann F, Weiner W (1929) Achylische Chloranämie. Klin Wochenschr 8:1071-1074 doi:10.1007/BF0176 1259

13. Poskitt EME (2003) Historical review. Early history of iron deficiency anaemia. Br J Haematol 122:554-562 doi:10.1046/j.1365-2141. 2003.04529.x

14. Kaznelson P (1942) Splenectomy in purpura haemorrhagica. Br Med J 14:591 Nov 